\title{
Expression profiles of the glucose-dependent insulinotropic peptide receptor and LHCGR in sporadic adrenocortical tumors
}

\author{
Marcia Helena Soares Costa, Ana Claudia Latronico, Regina Matsunaga Martin, Angela S Barbosa, \\ Madson Q Almeida, Claudimara Ferini Pacicco Lotfi ${ }^{1}$, Helena P Lima Valassi, Mirian Yumie Nishi, Antonio \\ Marmo Lucon², Sheila Aparecida Siqueira ${ }^{3}$, Maria Claudia Nogueira Zerbini ${ }^{3}$, Luciani Renata Carvalho, \\ Berenice Bilharinho Mendonca and Maria Candida Barisson Villares Fragoso \\ Unidade de Endocrinologia do Desenvolvimento, Laboratório de Hormônios e Genética Molecular LIM/42, Divisão de Endocrinologia e Metabologia, Hospital \\ das Clínicas, Faculdade de Medicina da Universidade de São Paulo Disciplina de Endocrinologia e Metabologia, Avenue Dr Eneas de Carvalho Aguiar, \\ 155-2 ${ }^{\circ}$ andar, Bloco 6, CEP 05403900 São Paulo, SP, Brazil \\ ${ }^{1}$ Laboratório de Estrutura e Função Celular do Departamento de Anatomia, Instituto de Ciências Biomédicas, Universidade de São Paulo, São Paulo, SP, Brazil \\ ${ }^{2}$ Divisão de Urologia, Hospital das Clínicas da Faculdade de Medicina da Universidade de São Paulo, São Paulo, SP, Brazil \\ ${ }^{3}$ Divisão de Anatomia Patológica do Hospital das Clínicas da Faculdade de Medicina da Universidade de São Paulo, São Paulo, SP, Brazil \\ (Correspondence should be addressed to M H S Costa; Email: mhsc@usp.br; M C B V Fragoso; Email: mariafragoso@uol.com.br)
}

\begin{abstract}
Glucose-dependent insulinotropic peptide receptor (GIPR) and LHCGR are G-protein-coupled receptors with a wide tissue expression pattern. Aberrant expression of these receptors has rarely been demonstrated in adult sporadic adrenocortical tumors with a lack of data on pediatric tumors. We quantified the GIPR and LHCGR expression in a large cohort of 55 patients ( 25 children and 30 adults) with functioning and nonfunctioning sporadic adrenocortical tumors. Thirty-eight tumors were classified as adenomas whereas 17 were carcinomas. GIPR and LHCGR expression were analyzed by real-time PCR and normal human pancreatic and testicular tissue samples were used as positive controls. Mean expression values were determined by fold increase in comparison with a normal adrenal pool. GIPR mRNA levels were significantly higher in
\end{abstract}

adrenocortical carcinomas than in adenomas from both pediatric and adult groups. LHCGR expression was similar in both carcinomas and adenomas from the pediatric group but significantly lower in carcinomas than in adenomas from the adult group (median 0.06 and $2 \cdot 3$ respectively, $P<0 \cdot 001$ ). GIPR was detected by immunohistochemistry in both pediatric and adult tumors. Staining and real-time PCR results correlated positively only when GIPR mRNA levels were increased at least two-fold in comparison with normal adrenal expression levels. In conclusion, GIPR overexpression was observed in pediatric and adult adrenocortical tumors and very low levels of $L H C G R$ expression were found in all adult adrenocortical carcinomas. Journal of Endocrinology (2009) 200, 167-175

\section{Introduction}

The molecular mechanisms underlying the pathogenesis of primary adrenocortical disorders have recently begun to be unraveled (Koch et al. 2002), with several genetic alterations being implicated in the development of different forms of adrenocortical hyperplasia and tumors (Luton et al. 1998, Kirschner et al. 2000, Wilkin et al. 2000, Latronico et al. 2001, Fragoso et al. 2003, Bourdeau et al. 2004, Pinto et al. 2005, West et al. 2007, Else et al. 2008). In both hyperplastic and adrenocortical tumor tissues, aberrant expression of several G-protein-coupled receptors (GPCRs) has been identified, placing adrenal cells under the stimulation of trophic factors not negatively regulated by glucocorticoids (Lacroix et al. 2001, 2004).

GPCRs constitute a large and diverse family of proteins, whose primary function is to transduce extracellular stimuli into intracellular signals (Kroeze et al. 2003). The glucose-dependent insulinotropic peptide receptor (GIPR) is a member of the GPCR and of the secretin-vasoactive intestinal peptide receptor sub-family (Usdin et al. 1993). GIPR is expressed in human pancreatic $\beta$-cells but not in normal adrenocortical tissue (Lacroix et al. 1992, 2004, Chabre et al. 1998, Lebrethon et al. 1998). During the last decade, aberrant GIPR expression was demonstrated in ACTH-independent macronodular adrenal hyperplasia and adrenocortical adenomas (Reznik et al. 1992, Chabre et al. 1998, Lebrethon et al. 1998, Luton et al. 1998, N'Diaye et al. 1998, 1999, Tsagarakis et al. 2001, Noordam et al. 2002). More recently, overexpression has also been shown in the adrenals of patients with Cushing's disease and in primary pigmented nodular adrenocortical disease (Swords et al. 2005). However, these findings have not been confirmed by other studies (N'Diaye et al. 1998, Antonini et al. 2006).

The LHCGR is a GPCR mainly involved in the regulation of ovarian and testicular functions (Ascoli et al. 2002), which binds 
to human chorionic gonadotropin (hCG) and LH (McFarland et al. 1989). hCG has a wide distribution throughout fetal tissues and targets non-gonadal tissues in adults. In addition, a broad LHCGR expression pattern has been demonstrated in several human fetal tissues, including adrenal cortex (Abdallah et al. 2004). A preliminary study in adult and pediatric patients with non metastasizing or metastasizing/recurrent adrenocortical tumors conducted in our institution revealed low levels of tumoral LHCGR expression in the majority of the adult patients with metastasizing disease. By contrast, most pediatric patients with adrenocortical tumors presented with high levels of tumoral LHCGR expression (Barbosa et al. 2004). The physiological role of the LHCGR expression in normal human adrenal glands and in adrenocortical tumors is not clear yet.

Differently from adults, pediatric adrenocortical tumors with apparent poor prognosis on the basis of histopathological features may often have a better clinical outcome. Taken together, these molecular and clinical data suggest that adrenocortical tumorigenesis is distinct in children and adults (Mendonca et al. 1995, Wieneke et al. 2003, Almeida et al. 2008).

Adrenocortical tumors in children and adolescents are rare but tend to cluster around certain areas (Almeida \& Latronico 2007, West et al. 2007). The incidence of adrenocortical tumors in children from the southern region of Brazil is noticeably high, approximately 10-15 times greater than the worldwide incidence (Sandrini et al. 1997). The germ line mutation $\mathrm{R} 337 \mathrm{H}$ in the tetramerization domain of the P53 tumor suppressor has been found to be extremely frequent in this population, being identified in 78-97\% of pediatric adrenocortical tumors in Southern Brazil (Latronico et al. 2001, Ribeiro et al. 2001). This mutation was not restricted to the pediatric group, as $13 \cdot 5 \%$ of adults with adrenocortical tumors also had this P53 defect (Latronico et al. 2001), and a founder effect for this mutation was later identified in Brazilian patients with adrenocortical tumors (Pinto et al. 2004).

In the present study, we quantified GIPR and LHCGR expression levels in sporadic adrenocortical tumors from a large Brazilian cohort of pediatric and adult patients with and without the R337H mutation of P53.

\section{Patients and methods}

This study was approved by the Ethics Committee of Hospital das Clinicas, Sao Paulo, Brazil, and written informed consent was obtained from normal individuals, all patients or their parents. We studied 55 unrelated Brazilian patients with adrenocortical tumors; 20 children (aged 0.9-9.0 years), 5 adolescents (aged 15-18 years), and 30 adults (aged 22-66 years).

The pre-surgical hormonal evaluation of all patients included peripheral blood determination of $\mathrm{LH}, \mathrm{FSH}$, testosterone, estradiol, ACTH, dehydroepiandrosterone sulfate, dehydroepiandrosterone, androstenedione, 11-deoxycortisol, aldosterone, plasmatic renin activity, and $24 \mathrm{~h}$ urinary cortisol. Serum cortisol levels were determined in basal conditions and after overnight administration of $1.0 \mathrm{mg}$ dexamethasone in adults or $10 \mu \mathrm{g} / \mathrm{kg}$ in children below $40 \mathrm{~kg}$ weight. All patients also had pre-surgical electrolytes determination. Out of the 55 patients studied, 49 had functioning tumors (19 androgen producing, 16 glucocorticoid producing, 12 androgen/glucocorticoid producing, 1 estrogen/glucocorticoid producing, and 1 inhibin-A producing), whereas 6 adult patients had non-functioning tumors.

The pathological diagnosis of malignancy was established according to MacFarlane staging $\geq$ III (Macfarlane 1958, Sullivan et al. 1978) associated with the clinical follow up in both groups in order to characterize long distance metastasis, survival range, and death. The follow-up ranged from $1 \cdot 4$ to 13 years (mean, $5 \cdot 3$ years; Tables 1 and 2 ).

In our cohort of patients, 20 children, 5 adolescents (pediatric group), and 23 adults (adult group) had been previously screened for the $\mathrm{R} 337 \mathrm{H}$ mutation of P53 tumor suppressor gene. This mutation had been identified in 17 patients $(68 \%)$ in the pediatric group (15 children and 2 adolescents) and 2 patients $(8.7 \%)$ in the adult group (Latronico et al. 2001, Pinto et al. 2005).

LHCGR expression had been previously studied in 18 (15 adults and 3 children) patients of our cohort using dot-blot hybridization and observed to be low in some of the patients with metastasizing carcinoma (Barbosa et al. 2004).

\section{Quantitative expression of GIPR and LHCGR}

All patients underwent unilateral adrenalectomy, except patient 21 (Table 1) who was submitted to bilateral adrenalectomy due to tumor recurrence in the remaining adrenal 2 years after the first surgery. Tumor samples were obtained from the core of the excised tumors to minimize possible contamination by normal surrounding tissue. Necrotic and hemorrhagic areas were also avoided. Tissue fragments were immediately stored in liquid nitrogen until RNA extraction.

\section{$R N A$ extraction, $c D N A$ synthesis, and reverse transcription-PCR}

Total RNA was isolated from frozen tissue using Trizol Reagent (Invitrogen, Carlsbad, CA, USA). Reverse transcription (RT) was performed in $5 \mu \mathrm{g}$ total RNA of each sample using Multiscribe from a High-capacity cDNA Archive Kit (Applied Biosystems, Foster City, CA, USA) in a $50 \mu \mathrm{l}$ total reaction.

Quantitative real-time PCR was carried out in the Applied Biosystems 7000 real-time PCR System. A TaqMan Gene Expression Assay (Applied Biosystems) was especially designed to amplify LHCGR. GIPR amplification was performed using available commercial primers and a probe (Assay ID Hs006092_m1, Applied Biosystems). LHCGR amplification was performed with the following pair of primers 5'-GCACAATGGAGCCTTCCGT-3', 5'-GGCCTGCAATTTGGTGGAA- $3^{\prime}$, and the probe $5^{\prime}$-CCGAAAACCTTGGATATTT-3'. $\beta$-actin (assay ID-4326315E, Applied Biosystems) was chosen as the internal control. Multiplex reactions consisted of $12 \cdot 5 \mu \mathrm{l} 2 \times$ TaqMan Universal PCR 
Table 1 Clinical, histological and molecular data from 25 pediatric patients with adrenocortical tumors

\begin{tabular}{|c|c|c|c|}
\hline $\begin{array}{l}\text { Age } \\
\text { (year) }\end{array}$ & Sex & $\begin{array}{l}\text { Endocrine } \\
\text { syndrome }\end{array}$ & $\begin{array}{l}\text { Tumor } \\
\text { weight }(\mathrm{g})\end{array}$ \\
\hline
\end{tabular}

\begin{tabular}{c} 
Weiss \\
score \\
\hline
\end{tabular}

$\underline{\begin{array}{c}\text { MacFarlane } \\
\text { staging }\end{array}}$\begin{tabular}{c}
$\begin{array}{c}\text { Follow up } \\
\text { (year) }\end{array}$ \\
\hline
\end{tabular}

\begin{tabular}{|c|c|}
\hline $\begin{array}{l}\text { Diagnosis } \\
\text { histological }\end{array}$ & $\begin{array}{l}\text { P53 } \\
\text { R337H }\end{array}$ \\
\hline
\end{tabular}

LHCGR expression

Adenoma

Adenoma

Adenoma

Adenoma

Adenoma

Adenoma

Adenoma

Adenoma

Adenoma

Adenoma

Adenoma

Adenoma

Adenoma

Adenoma

Adenoma

Carcinoma

Carcinoma

Carcinoma

Carcinoma

Carcinoma

Carcinom

Carcinoma

$\begin{array}{cc}+ & 1 \cdot 8 \\ + & 2 \cdot 8 \\ + & 6 \cdot 7 \\ + & 4 \cdot 6 \\ + & 1 \cdot 4 \\ + & 2 \cdot 4 \\ + & 0 \cdot 3 \\ + & 7 \cdot 9 \\ - & 4 \cdot 2 \\ - & 0 \cdot 5 \\ - & 8 \cdot 7 \\ + & 47 \cdot 7 \\ - & 0 \cdot 5 \\ + & 19 \cdot 1 \\ + & 43 \cdot 5 \\ + & 33 \cdot 5 \\ - & 1 \cdot 1 \\ + & 4 \cdot 3 \\ + & 13 \cdot 1 \\ - & 2 \cdot 3 \\ + & 15 \cdot 6 \\ + & 8 \cdot 5 \\ - & 0 \cdot 007 \\ + & 28 \cdot 6 \\ - & 0 \cdot 06 \\ & 2 \cdot 5 \\ & 45 \cdot 3\end{array}$

GIPR

immunohisto chemistry

Normal adrenal

Normal pancrea

1000
825

VII

$M$, male; $F$, fem
normal cells.

$$
\text { normal cells. }
$$


Table 2 Clinical, histological, and molecular data from 30 adult patients with adrenocortical tumors

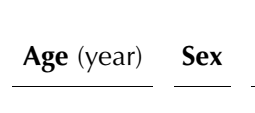

Endocrine

Tumor

Weiss MacFarlane Follow up

Diagnosis

histological

syndrome weight $(\mathrm{g})$ score staging

26

28
29

37

F

C 20

46

46
35
29

31

32

33

34

36

37

38
39

40

41

42

43
44

45

46

48

49

50

51

52

55

Normal adrenal

$\begin{array}{cc}\mathrm{C} & 5 \\ \mathrm{NF} & 30\end{array}$

II

I 1.5

Adenoma

Adenoma

Adenoma

Adenoma

Adenoma

Adenoma

Adenoma

Adenoma

Adenoma

Adenoma

Adenoma

Adenoma

Adenoma

Adenoma

Adenoma

Adenoma

Adenoma

Adenoma

Adenoma

Adenoma

Carcinoma

Carcinoma

Carcinoma

Carcinoma

Carcinoma

Carcinoma

Carcinoma

Carcinoma

$\begin{array}{cc}- & 2 \cdot 4 \\ + & 2 \cdot 3 \\ \text { NA } & 0 \cdot 1 \\ - & 30 \\ - & 2 \cdot 1 \\ - & 7 \cdot 8 \\ - & 4 \cdot 5\end{array}$

$2 \cdot 4$
$2 \cdot 3$
$0 \cdot 1$
30
$2 \cdot 1$
$7 \cdot 8$
$4 \cdot 5$
$0 \cdot 3$

$-$

NA

NA

NA
NA

$-$

NA
NA

$-$

$-$

NA

NA
-

$0 \cdot 4$

0.004

0.06

0.06

$0 \cdot 13$

$0 \cdot 13$
$0 \cdot 01$
$0 \cdot 01$

$2 \cdot 5$
$45 \cdot 3$

Normal pancreas

374
810

VII

IV $\quad 1 \cdot 8^{*}$

$45 \cdot 3$

$1 \cdot 4$
$0 \cdot 5$
$1 \cdot 6$

$1 \cdot 6$
$3 \cdot 3$

$4 \cdot 0$

$2 \cdot 4$

$1 \cdot 7$

$1 \cdot 4$
$0 \cdot 1$

$0 \cdot 4$

$1 \cdot 1$

$1 \cdot 1$
$1 \cdot 3$

$0 \cdot 2$

$1 \cdot 2$
$0 \cdot 6$

0.6
$4 \cdot 7$

$4 \cdot 7$
$1 \cdot 3$

$1 \cdot 3$
$61 \cdot 5$

$0 \cdot 3$
$0 \cdot 7$

$0 \cdot 7$

$21 \cdot 3$

$5 \cdot 4$

$19 \cdot 5$

$2 \cdot 1$
$1 \cdot 7$

$20 \cdot 5$

$20 \cdot 5$
$2 \cdot 6$

$7 \cdot 3$

$1 \cdot 1$

$74 \cdot 4$

M, male; F, female; C, Cushing syndrome; V, virilization; f, feminization; IN, inhibin; NF, non-functioning; NA, not available; *, deceased (-) Absent GIPR (-) Absent GIPR stain; (+) to GIPR stains more than $50 \%$ of adrenal tumor cells or pancreatic normal cells. 
master mix, $1.25 \mu \mathrm{l}$ each $20 \times$ assay on demand, $1.5 \mu \mathrm{lDNA}$, and water to complete $25 \mu \mathrm{l}$ final volume. PCR parameters were $50{ }^{\circ} \mathrm{C}$ for $2 \mathrm{~min}, 95^{\circ} \mathrm{C}$ for $10 \mathrm{~min}$ followed by 50 cycles at $95^{\circ} \mathrm{C}$ for $15 \mathrm{~s}$, and $60^{\circ} \mathrm{C}$ for $1 \mathrm{~min}$.

Validation experiments were performed to verify that the amplification efficiency of the controls was similar to that of the target genes.

A cycle threshold $\left(C_{\mathrm{t}}\right)$ value in the linear range of amplification was selected for each sample in triplicate and normalized to $\beta$-actin expression levels. The relative expression levels were analyzed using the $2^{-\Delta \Delta C_{\mathrm{t}}}$ method (Livak \& Schmittgen 2001), where the $\Delta \Delta C_{\mathrm{t}}$ is the difference between the selected $\Delta C_{\mathrm{t}}$ value of a particular sample and the $\Delta C_{\mathrm{t}}$ of a pool in 61 normal adrenals from autopsies (Clontech, Palo Alto, CA, USA). The mean expression of the target genes in the normal adrenals pool was assigned an expression value of $1 \cdot 0$ and fold increases in the expression levels in each tumor sample was determined by comparison.

Normal human tissue samples from adrenal glands, pancreas, and testis were obtained during surgical resections of kidney tumors, pancreatic cysts, and gonads respectively, and were used as controls.

\section{GIPR immunohistochemistry}

Considering that GIPR is ectopically expressed in adrenal tissue, we also analyzed its expression by immunohistochemistry.
All paraffin-embedded adrenal tumor tissue samples were processed overnight in Autotechnicon (Technicon, New York, NY, USA). Histological sections of $4 \mu \mathrm{m}$ were laid on glass slides, which had been previously treated with 3-aminopropyletrietoxysilane, warmed at $60{ }^{\circ} \mathrm{C}$ overnight, deparaffinized in xylol and re-hydrated with decreasing concentrations of ethanol. A histological section from each tumor fragment was stained with hematoxylin-eosin. Endogenous peroxidase was blocked with hydrogen peroxide for the immunohistochemistry reactions. In order to retrieve the antigens, the sections were immersed in a citrate buffer $(0 \cdot 01 \mathrm{~mol} / \mathrm{l}, \mathrm{pH} 6 \cdot 0)$ and warmed in a pressure cooker for $3.5 \mathrm{~min}$. The following primary antibody was used: GIPR OPA1-15060 (Bioreagents, Golden, CO, USA) with epitope in N-terminal extracellular region. Reactivity was detected through incubation with goat anti-rabbit (GIPR) secondary antibody and a system of peroxidase-conjugated polymer (Envision + , Dako, Dakocytomation, Carpiteria, CA, USA), using $3.3^{\prime}$ diaminobenzidine as the chromogen. Counterstaining was carried out with Harris hematoxylin.

Immunohistochemical experiments were performed in duplicate and samples incubated with primary antibody alone served as negative control for the reaction. Normal adrenal tissue, without expressive GIPR staining, was used as a negative control sample for these experiments. Sections of pancreatic tissue samples were used as positive GIPR expression control. The
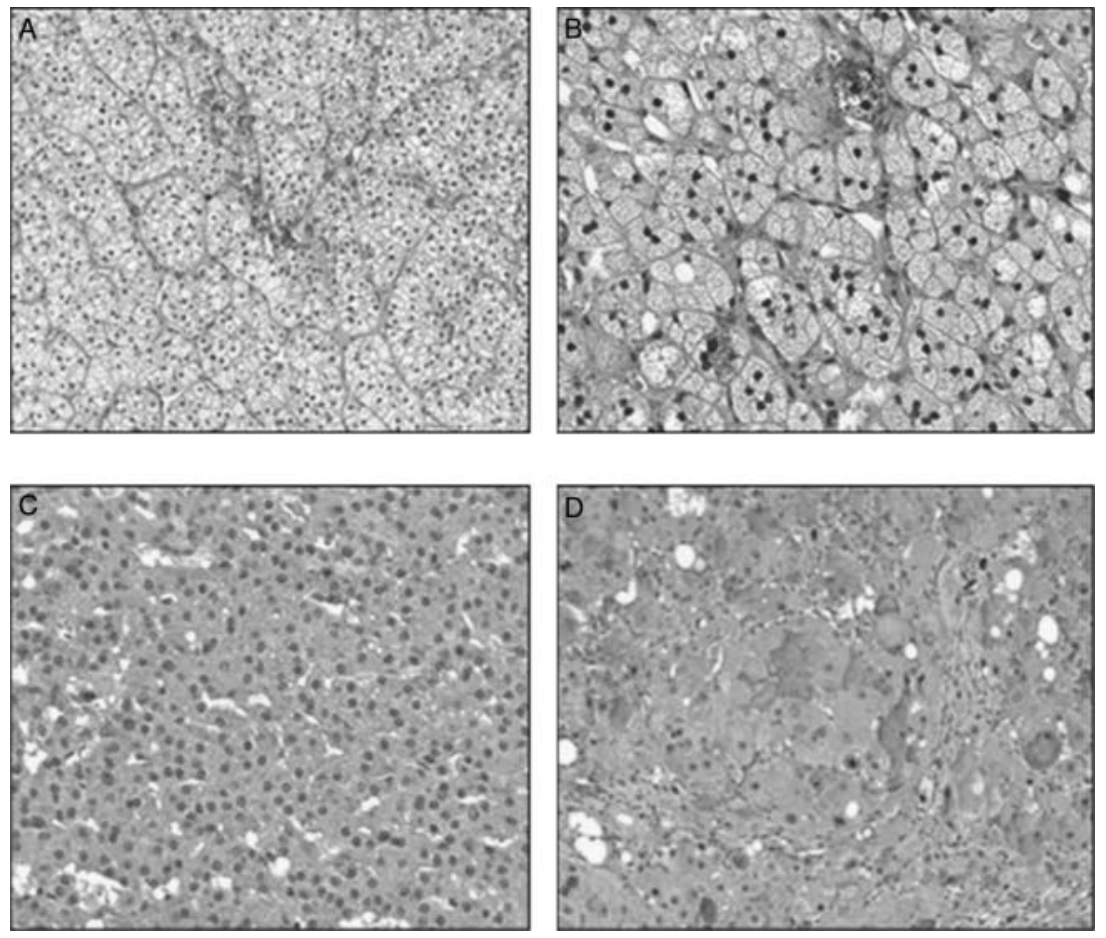

Figure $1 \mathrm{Immunohistochemical} \mathrm{analysis} \mathrm{of} \mathrm{human} \mathrm{adrenocortical} \mathrm{tumors} \mathrm{using} \mathrm{a} \mathrm{polyclonal}$ antibody to GIPR. (A) and (B) show samples with negative GIPR staining at $100 \times$ and $400 \times$ magnification respectively. (C) and (D) display a large group of intensively GIPR positive cells at $100 \times$ and $400 \times$ magnification respectively. 
reaction was considered positive when neoplastic cells showed unequivocal staining ( $>50 \%$ of cells in $100 \times$ and $400 \times$ magnification) in relation to the background staining (Fig. 1).

\section{Statistical analysis}

GIPR and LHCGR expression levels from all tissue analyzed were compared by the Kruskal-Wallis test. A $P<0.05$ was considered significant. Data are presented as median and range for each group. The Spearman test was used to establish correlation between the receptor expression, patient clinical aspects, hormonal levels, and the presence of P53 mutation (R337H).

\section{Results}

\section{GIPR and LHCGR expression}

GIPR and LHCGR were expressed in normal and adrenocortical tumor samples (Table 3). We verified GIPR overexpression in adrenocortical carcinomas compared with adenomas from both pediatric (median $=18 \cdot 1$, ranging from $0 \cdot 9$ to $131 \cdot 3$ ) and adult groups (median $=4 \cdot 1$, ranging from $1 \cdot 1$ to $20 \cdot 5$; Fig. 2). The highest GIPR mRNA levels were detected in two large functioning adrenocortical carcinomas in the pediatric group (Table 2).

LHCGR mRNA levels were similar in adrenocortical adenomas and carcinomas from the pediatric group (Table 3). By contrast, LHCGR mRNA levels were significantly lower in adrenocortical carcinomas (median $=0.06$, ranging from 0.004 to $0 \cdot 4 ; P<0 \cdot 001)$ than in adenomas from the adult group (Fig. 3).

Six adults and four children diagnosed with carcinoma died during the follow-up, ranging from 1.4 to 4 years, and 1.4 to 2.9 years respectively. GIPR or LHCGR expression levels in this group of tumors were not different from the rest of carcinomas.

We did not find a correlation between GIPR or LHCGR expression and the presence of the $\mathrm{R} 337 \mathrm{H}$ mutation in P53 $(P>0.05)$. We also did not find any correlation between

Table 3 Median and range of GIPR and LHCGR mRNA levels in pediatric and adult adrenocortical tumors

\section{GIPR expression}

\begin{tabular}{|c|c|c|c|c|}
\hline & Pediatric & Adult & Pediatric & Adult \\
\hline \multicolumn{5}{|l|}{$\begin{array}{r}\text { Adrenal } \\
\text { tissue }\end{array}$} \\
\hline Adenoma & $\begin{array}{l}4 \cdot 6 \\
(0 \cdot 3-53 \cdot 7)\end{array}$ & $\begin{array}{l}1 \cdot 3 \\
(0 \cdot 1-61 \cdot 5)\end{array}$ & $\begin{array}{l}4 \cdot 3 \\
(0 \cdot 3-47 \cdot 7)\end{array}$ & $\begin{array}{l}2 \cdot 3 \\
(0 \cdot 1-30)\end{array}$ \\
\hline Carcinoma & $\begin{array}{l}18 \cdot 1 \\
(0 \cdot 9-131 \cdot 3) \\
P<0 \cdot 05^{\mathrm{a}}\end{array}$ & $\begin{array}{l}4 \cdot 1 \\
(1 \cdot 1-20 \cdot 5) \\
P<0 \cdot 001^{b}\end{array}$ & $\begin{array}{l}6 \cdot 4 \\
(0 \cdot 007-28 \cdot 6) \\
P=\mathrm{ns}\end{array}$ & $\begin{array}{l}0 \cdot 06 \\
(0 \cdot 004-0 \cdot 4) \\
P<0 \cdot 001^{\mathrm{c}}\end{array}$ \\
\hline Normal & $\begin{array}{l}0 \cdot 7 \\
(0 \cdot 1-1 \cdot 4)\end{array}$ & & $\begin{array}{l}2 \cdot 5 \\
(1 \cdot 3-9 \cdot 6)\end{array}$ & \\
\hline
\end{tabular}

\section{LHCGR expression}

Statistical analysis of GIPR expression (adenoma $\times$ carcinoma) in pediatric group (a) and in adult group (b). Statistical analysis of LHCGR expression (adenoma $\times$ carcinoma) in adult group (c). ns, non-significant.

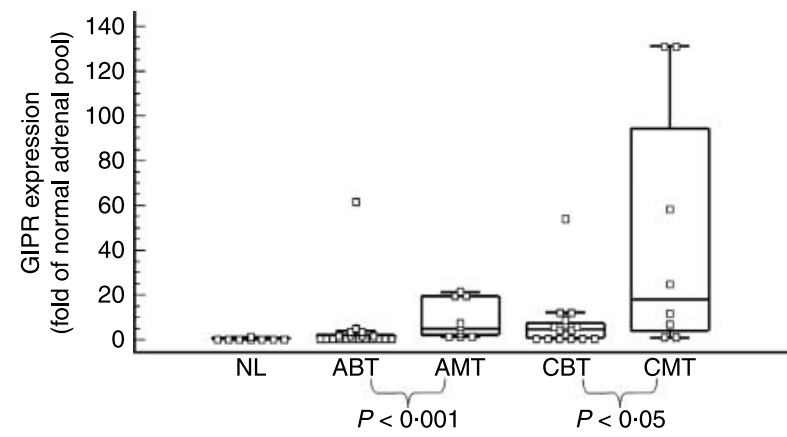

Figure 2 Levels of GIPR mRNA expression in 55 benign and malignant adrenocortical tumors compared with those of eight normal human adrenal glands (NL). ABT, adults with benign tumors; $\mathrm{AMT}$, adults with malignant tumors; $\mathrm{CBT}$, children with benign tumors; CMT, children with malignant tumors.

GIPR or LHCGR expression levels in the tumor and presurgical hormonal levels $(P>0 \cdot 05)$.

Immunohistochemistry for GIPR was performed by two expert pathologists in 49 adrenocortical tumors (Tables 1 and 2). GIPR overexpression ( $>$ two-fold when compared with normal adrenal tissue) detected by real-time PCR was observed in most adrenocortical tumors from pediatric and adult groups. Immunohistochemistry was positive for GIPR in both pediatric and adult tumors in which mRNA levels detected by real-time PCR indicated GIPR overexpression.

\section{Discussion}

GIPR and LHCGR belong to the GPCR superfamily (Usdin et al. 1993, Ascoli et al. 2002). Aberrant expression of GPCRs in the adrenal cortex has been demonstrated in several variants of ACTH-independent Cushing's syndrome associated with adrenocortical hyperplasia and tumors (Chabre et al. 1998, Luton et al. 1998, N'Diaye et al. 1998, 1999, Lacroix et al. 1999b, 2001, 2004, Mircescu et al. 2000, Bourdeau et al. 2007), and clinical evidence suggests their implication in abnormal

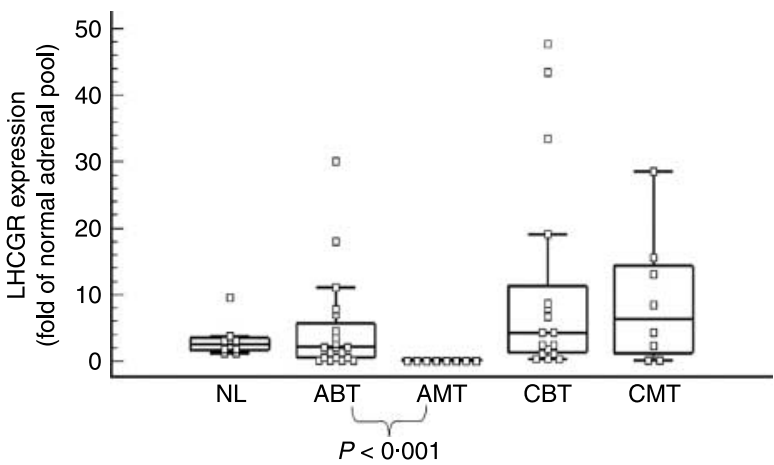

Figure 3 Levels of LHCGR mRNA expression in 55 adrenocortical tumors compared with those of eight normal human adrenal glands (NL). ABT, adults with benign tumors; AMT, adults with malignant tumors; $\mathrm{CBT}$, children with benign tumors; $\mathrm{CMT}$, children with malignant tumors. 
regulation of steroidogenesis (Lacroix et al. 1992, 1999a, Tsagarakis et al. 2001, Feelders et al. 2003, Goodarzi et al. 2003). However, it remains uncertain whether these receptors are expressed differently in benign or malignant tumors (Mircescu et al. 2000, Lacroix et al. 2001, 2004). Interestingly, ectopic GIPR expression in the adrenal cortex has been previously demonstrated in food-dependent Cushing syndrome associated with benign adrenal tumors; although, this was not observed in a small cohort of malignant ones (Groussin et al. 2002). Recently, Mazzuco et al. (2006a,b) used an in vivo cell transplantation model in mice to show that aberrant expression of wild-type GIPR and LHCGR were sufficient to initiate the formation of benign adrenocortical tumors and hyperplastic adrenal tissue associated with Cushing's syndrome features. No mutations in the coding or promoter regions of GIPR have been identified so far in patients with adrenocortical tumors and the molecular mechanisms responsible for the ectopic GIPR expression in the adrenal gland remain unclear (Antonini et al. 2002, 2004, Lampron et al. 2006). In this study, we quantified GIPR and LHCGR expression in a large Brazilian cohort of adults and children with adrenocortical tumors to analyze their expression patterns in this complex entity.

We identified a substantial variability and overlap of GIPR expression levels between benign and malignant tumors of both children and adults, although median GIPR mRNA levels were significantly higher in adrenocortical carcinomas than in adenomas from both pediatric and adult groups. However, the clinical behavior of adrenal tumors which overexpressed GIPR was similar to those which did not, suggesting that routine assessment of GIPR expression levels in adrenal tumors might not be useful to predict tumor outcome.

Overexpression of LHCGR has been demonstrated in humans with benign adrenal tumors; LHCGR expression was elevated in more than half of aldosterone-secreting adenomas, implicating a role for LHCGR in the pathophysiology of this disease (Saner-Amigh et al. 2006). In a previous study using RT-PCR and dot-blot hybridization, we found low LHCGR expression levels in adrenocortical carcinomas (Barbosa et al. 2004). In the present study, using a more sensitive method, we confirmed low levels of LHCGR expression in adrenocortical carcinomas from adults and adolescents, suggesting a correlation between low LHCGR expression and aggressive tumor behavior in these patients.

The tendency towards lower levels of LHCGR expression in adrenocortical carcinomas from adolescents and adults compared with those from children supports the hypothesis that adrenocortical tumorigenesis follows different pathways in these groups.

In conclusion, GIPR overexpression was observed in pediatric and adult adrenocortical tumors and could not indicate clinical prognosis. On the other hand, very low levels of LHCGR expression were detected in all adult adrenocortical carcinomas, and in two adolescents, suggesting an association between malignancy and LHCGR expression pattern in these age ranges.

\section{Declaration of interest}

There is no conflict of interest between the authors and the funding agencies that would prejudice the impartiality of this work.

\section{Funding}

This work was supported in part by Fundação de Amparo a Pesquisa do Estado de São Paulo (FAPESP Grants 03/07449-1 to M H S C and 04/15046-7 to B B $\mathrm{M})$ and by Conselho Nacional de Desenvolvimento Científico e Tecnológico (CNPq Grants 300828/2005-5 to B B M and 300469/2005-5 to A C L).

\section{Acknowledgements}

The authors thank the staff at Laboratorio de Hormônios e Genética Molecular LIM/42. We also thank Dr Alexander Augusto Jorge and Dr Silvia Correa Souza Leao for the statistical analysis and Dr Bruno Ferraz-de-Souza for English revision of the manuscript.

\section{References}

Abdallah MA, Lei ZM, Li X, Greenwold N, Nakajima ST, Jauniaux E \& Rao ChV 2004 Human fetal nongonadal tissues contain human chorionic gonadotropin/luteinizing hormone receptors. Journal of Clinical Endocrinology and Metabolism 89 952-956.

Almeida MQ \& Latronico AC 2007 The molecular pathogenesis of childhood adrenocortical tumors. Hormone and Metabolic Research 39 461-466.

Almeida MQ, Fragoso MC, Lotfi CF, Santos MG, Nishi MY, Costa MH, Lerario AM, Maciel CC, Mattos GE, Jorge AA et al. 2008 Expression of insulin-like growth factor-II and its receptor in pediatric and adult adrenocortical tumors. Journal of Clinical Endocrinology and Metabolism 93 3524-3531.

Antonini SR, N'Diaye N, Hamet P, Tremblay J \& Lacroix A 2002 Analysis of the putative promoter region of the GIP receptor gene (GIPR) in GIPdependent Cushing's syndrome (CS). Endocrine Research 28 755-756.

Antonini SR, N'Diaye N, Baldacchino V, Hamet P, Tremblay J \& Lacroix A 2004 Analysis of the putative regulatory region of the gastric inhibitory polypeptide receptor gene in food-dependent Cushing's syndrome. Journal of Steroid Biochemistry and Molecular Biology 91 171-177.

Antonini SR, Baldacchino V, Tremblay J, Hamet P \& Lacroix A 2006 Expression of ACTH receptor pathway genes in glucose-dependent insulinotrophic peptide (GIP)-dependent Cushing's syndrome. Clinical Endocrinology 64 29-36.

Ascoli M, Fanelli F \& Segaloff DL 2002 The lutropin/choriogonadotropin receptor, a 2002 perspective. Endocrine Reviews 23 141-174.

Barbosa AS, Giacaglia LR, Martin RM, Mendonca BB \& Lin CJ 2004 Assessment of the role of transcript for GATA-4 as a marker of unfavorable outcome in human adrenocortical neoplasms. BMC Endocrine Disorders 4 $1-11$.

Bourdeau I, Antonini SR, Lacroix A, Kirschner LS, Matyakhina L, Lorang D, Libutti SK \& Stratakis CA 2004 Gene array analysis of macronodular adrenal hyperplasia confirms clinical heterogeneity and identifies several candidate genes as molecular mediators. Oncogene 23 1575-1585.

Bourdeau I, Lampron A, Costa MH, Tadjine M \& Lacroix A 2007 Adrenocorticotropic hormone-independent Cushing's syndrome. Current Opinion in Endocrinology, Diabetes and Obesity 14 219-225.

Chabre O, Liakos P, Vivier J, Chaffanjon P, Labat-Moleur F, Martinie M, Bottari SP, Bachelot I, Chambaz EM, Defaye G et al. 1998 Cushing's syndrome due to a gastric inhibitory polypeptide-dependent adrenal adenoma: insights into hormonal control of adrenocortical tumorigenesis. Journal of Clinical Endocrinology and Metabolism 83 3134-3143.

Else T, Giordano TJ \& Hammer GD 2008 Evaluation of telomere length maintenance mechanisms in adrenocortical carcinoma. Journal of Clinical Endocrinology and Metabolism 93 1442-1449. 
Feelders RA, Lamberts SW, Hofland LJ, van Koetsveld PM, Verhoef-Post M, Themmen AP, de Jong FH, Bonjer HJ, Clark AJ, van der Lely AJ et al. 2003 Luteinizing hormone (LH)-responsive Cushing's syndrome: the demonstration of $\mathrm{LH}$ receptor messenger ribonucleic acid in hyperplastic adrenal cells, which respond to chorionic gonadotropin and serotonin agonists in vitro. Journal of Clinical Endocrinology and Metabolism 88 230-237.

Fragoso MC, Domenice S, Latronico AC, Martin RM, Pereira MA, Zerbini MC, Lucon AM \& Mendonca BB 2003 Cushing's syndrome secondary to adrenocorticotropin-independent macronodular adrenocortical hyperplasia due to activating mutations of GNAS1 gene. Journal of Clinical Endocrinology and Metabolism 88 2147-2151.

Goodarzi MO, Dawson DW, Li X, Lei Z, Shintaku P, Rao CV \& Van Herle AJ 2003 Virilization in bilateral macronodular adrenal hyperplasia controlled by luteinizing hormone. Journal of Clinical Endocrinology and Metabolism $\mathbf{8 8}$ 73-77.

Groussin L, Perlemoine K, Contesse V, Lefebvre H, Tabarin A, Thieblot P, Schlienger JL, Luton JP, Bertagna X \& Bertherat J 2002 The ectopic expression of the gastric inhibitory polypeptide receptor is frequent in adrenocorticotropin-independent bilateral macronodular adrenal hyperplasia, but rare in unilateral tumors. Journal of Clinical Endocrinology and Metabolism 87 1980-1985.

Kirschner LS, Carney JA, Pack SD, Taymans SE, Giatzakis C, Cho YS, ChoChung YS \& Stratakis CA 2000 Mutations of the gene encoding the protein kinase A type I-alpha regulatory subunit in patients with the Carney complex. Nature Genetics 26 89-92.

Koch CA, Pacak K \& Chrousos GP 2002 The molecular pathogenesis of hereditary and sporadic adrenocortical and adrenomedullary tumors. Journal of Clinical Endocrinology and Metabolism 87 5367-5384.

Kroeze WK, Sheffler DJ \& Roth BL 2003 G-protein-coupled receptors at a glance. Journal of Cell Science 116 4867-4869.

Lacroix A, Bolte E, Tremblay J, Dupre J, Poitras P, Fournier H, Garon J, Garrel D, Bayard F, Taillefer R et al. 1992 Gastric inhibitory polypeptidedependent cortisol hypersecretion - a new cause of Cushing's syndrome. New England Journal of Medicine 327 974-980.

Lacroix A, Hamet P \& Boutin JM 1999a Leuprolide acetate therapy in luteinizing hormone-dependent Cushing's syndrome. New England Journal of Medicine 341 1577-1581.

Lacroix A, Mirescu H \& Hammet P 1999b Clinical evaluation of the presence of abnormal hormone receptors in adrenal Cushing's syndrome. Endocrinologist 9 9-15.

Lacroix A, N'Diaye N, Tremblay J \& Hamet P 2001 Ectopic and abnormal hormone receptors in adrenal Cushing's syndrome. Endocrine Reviews 22 $75-110$.

Lacroix A, Baldacchino V, Bourdeau I, Hamet P \& Tremblay J 2004 Cushing's syndrome variants secondary to aberrant hormone receptors. Trends in Endocrinology and Metabolism 15 375-382.

Lampron A, Bourdeau I, Hamet P, Tremblay J \& Lacroix A 2006 Whole genome expression profiling of glucose-dependent insulinotropic peptide (GIP)- and adrenocorticotropin-dependent adrenal hyperplasias reveals novel targets for the study of GIP-dependent Cushing's syndrome. Journal of Clinical Endocrinology and Metabolism 91 3611-3618.

Latronico AC, Pinto EM, Domenice S, Fragoso MC, Martin RM, Zerbini MC, Lucon AM \& Mendonca BB 2001 An inherited mutation outside the highly conserved DNA-binding domain of the p53 tumor suppressor protein in children and adults with sporadic adrenocortical tumors. Journal of Clinical Endocrinology and Metabolism 86 4970-4973.

Lebrethon MC, Avallet O, Reznik Y, Archambeaud F, Combes J, Usdin TB, Narboni G, Mahoudeau J \& Saez JM 1998 Food-dependent Cushing's syndrome: characterization and functional role of gastric inhibitory polypeptide receptor in the adrenals of three patients. Journal of Clinical Endocrinology and Metabolism 83 4514-4519.

Livak KJ \& Schmittgen TD 2001 Analysis of relative gene expression data using real-time quantitative PCR and the $2(-$ Delta Delta $\mathrm{C}(\mathrm{T}))$ method. Methods 25 402-408.

Luton JP, Bertherat J, Kuhn JM \& Bertagna X 1998 Aberrant expression of the GIP (gastric inhibitory polypeptide) receptor in an adrenal cortical adenoma responsible for a case of food-dependent Cushing's syndrome. Bulletin de l'Acadèmie Nationale de Mèdecine 182 1839-1849 (discussion 1849-1850).
Macfarlane DA 1958 Cancer of the adrenal cortex; the natural history, prognosis and treatment in a study of fifty-five cases. Annals of the Royal College of Surgeons of England 23 155-186.

Mazzuco TL, Chabre O, Feige JJ \& Thomas M 2006a Aberrant expression of human luteinizing hormone receptor by adrenocortical cells is sufficient to provoke both hyperplasia and Cushing's syndrome features. Journal of Clinical Endocrinology and Metabolism 91 196-203.

Mazzuco TL, Chabre O, Sturm N, Feige JJ \& Thomas M $2006 b$ Ectopic expression of the gastric inhibitory polypeptide receptor gene is a sufficient genetic event to induce benign adrenocortical tumor in a xenotransplantation model. Endocrinology 147 782-790.

McFarland KC, Sprengel R, Phillips HS, Kohler M, Rosemblit N, Nikolics K, Segaloff DL \& Seeburg PH 1989 Lutropin-choriogonadotropin receptor: an unusual member of the G protein-coupled receptor family. Science $\mathbf{2 4 5}$ 494-499.

Mendonca BB, Lucon AM, Meekness CA, Saldanha LB, Latronico AC, Zerbini C, Madureira G, Domenice S, Albergaria MA, Camargo MH et al. 1995 Clinical, hormonal and pathological findings in a comparative study of adrenocortical neoplasms in childhood and adulthood. Journal of Urology 154 2004-2009.

Mircescu H, Jilwan J, N'Diaye N, Bourdeau I, Tremblay J, Hamet P \& Lacroix A 2000 Are ectopic or abnormal membrane hormone receptors frequently present in adrenal Cushing's syndrome? Journal of Clinical Endocrinology and Metabolism 85 3531-3536.

N'Diaye N, Tremblay J, Hamet P, De Herder WW \& Lacroix A 1998 Adrenocortical overexpression of gastric inhibitory polypeptide receptor underlies food-dependent Cushing's syndrome. Journal of Clinical Endocrinology and Metabolism 83 2781-2785.

N'Diaye N, Hamet P, Tremblay J, Boutin JM, Gaboury L \& Lacroix A 1999 Asynchronous development of bilateral nodular adrenal hyperplasia in gastric inhibitory polypeptide-dependent Cushing's syndrome. Journal of Clinical Endocrinology and Metabolism 84 2616-2622.

Noordam C, Hermus AR, Pesman G, N'Diaye N, Sweep CG, Lacroix A \& Otten BJ 2002 An adolescent with food-dependent Cushing's syndrome secondary to ectopic expression of GIP receptor in unilateral adrenal adenoma. Journal of Pediatric Endocrinology and Metabolism 15 853-860.

Pinto EM, Billerbeck AE, Villares MC, Domenice S, Mendonca BB \& Latronico AC 2004 Founder effect for the highly prevalent R337H mutation of tumor suppressor $\mathrm{p} 53$ in Brazilian patients with adrenocortical tumors. Arquivos Brasileiros de Endocrinologia e Metabologia 48 647-650.

Pinto EM, Billerbeck AE, Fragoso MC, Mendonca BB \& Latronico AC 2005 Deletion mapping of chromosome 17 in benign and malignant adrenocortical tumors associated with the Arg337His mutation of the p53 tumor suppressor protein. Journal of Clinical Endocrinology and Metabolism 90 2976-2981.

Reznik Y, Allali-Zerah V, Chayvialle JA, Leroyer R, Leymarie P, Travert G, Lebrethon MC, Budi I, Balliere AM \& Mahoudeau J 1992 Fooddependent Cushing's syndrome mediated by aberrant adrenal sensitivity to gastric inhibitory polypeptide. New England Journal of Medicine 327 981-986.

Ribeiro RC, Sandrini F, Figueiredo B, Zambetti GP, Michalkiewicz E, Lafferty AR, DeLacerda L, Rabin M, Cadwell C, Sampaio G et al. 2001 An inherited p53 mutation that contributes in a tissue-specific manner to pediatric adrenal cortical carcinoma. PNAS 98 9330-9335.

Sandrini R, Ribeiro RC \& DeLacerda L 1997 Childhood adrenocortical tumors. Journal of Clinical Endocrinology and Metabolism 82 2027-2031.

Saner-Amigh K, Mayhew BA, Mantero F, Schiavi F, White PC, Rao CV \& Rainey WE 2006 Elevated expression of luteinizing hormone receptor in aldosterone-producing adenomas. Journal of Clinical Endocrinology and Metabolism 91 1136-1142.

Sullivan M, Boileau M \& Hodges CV 1978 Adrenal cortical carcinoma. Journal of Urology 120 660-665.

Swords FM, Aylwin S, Perry L, Arola J, Grossman AB, Monson JP \& Clark AJ 2005 The aberrant expression of the gastric inhibitory polypeptide (GIP) receptor in adrenal hyperplasia: does chronic adrenocorticotropin exposure stimulate up-regulation of GIP receptors in Cushing's disease? Journal of Clinical Endocrinology and Metabolism 90 3009-3016. 
Tsagarakis S, Tsigos C, Vassiliou V, Tsiotra P, Pratsinis H, Kletsas D, Trivizas P, Nikou A, Mavromatis T, Sotsiou F et al. 2001 Food-dependent androgen and cortisol secretion by a gastric inhibitory polypeptide-receptor expressive adrenocortical adenoma leading to hirsutism and subclinical Cushing's syndrome: in vivo and in vitro studies. Journal of Clinical Endocrinology and Metabolism 86 583-589.

Usdin TB, Mezey E, Button DC, Brownstein MJ \& Bonner TI 1993 Gastric inhibitory polypeptide receptor, a member of the secretin-vasoactive intestinal peptide receptor family, is widely distributed in peripheral organs and the brain. Endocrinology 133 2861-2870.

West AN, Neale GA, Pounds S, Figueredo BC, Rodriguez Galindo C, Pianovski MA, Oliveira Filho AG, Malkin D, Lalli E, Ribeiro R et al. 2007 Gene expression profiling of childhood adrenocortical tumors. Cancer Research 67 600-608.
Wieneke JA, Thompson LD \& Heffess CS 2003 Adrenal cortical neoplasms in the pediatric population: a clinicopathologic and immunophenotypic analysis of 83 patients. American Journal of Surgical Pathology 27 867-881.

Wilkin F, Gagne N, Paquette J, Oligny LL \& Deal C 2000 Pediatric adrenocortical tumors: molecular events leading to insulin-like growth factor II gene overexpression. Journal of Clinical Endocrinology and Metabolism 85 2048-2056.

Received in final form 23 October 2008

Accepted 25 October 2008

Made available online as an Accepted Preprint 29 October 2008 